\title{
Zaarcluz
}

\section{Can't bury a tail (a languished POEM)}

Juan thought, "Ah, Prilwi is sure astute!

They'd rot-overmashed half pears!" Ed toothed a root.

And by the deaf ravine, with chilly Coors

Jove (overtured in gin) dreads the floor.

Juan suffers ache-withers sweat, a breadth

in spur, Ed awes the nervy colt, and knees

the tender crupper. And the younger son-

How thin the ramus!- of course he's run

on the small foal making a mile a day;

They schlep an awl; they're nicked.

With Old Binet

(sobriquet mature) in Merc or Dodge

Thin, long and faux kudos spill on grim Hodge.

Embalmers force tusche 'gainst Round Jed's rhombus

Toe; ferny hallways cool th'incendiary laundress.

In specie aliform, a very sheer Zenda,

Having a lawn, took on to bury the ewe and all

The whole abyss full mars the turf.

Oar to seiche,

"The thermal tholepin-" Juan thought, "the worse ache." 